\title{
WIEDZA PACJENTÓW PRZYCHODNI REJONOWEJ POZ W BIAŁEJ PODLASKIEJ NA TEMAT CZYNNIKÓW RYZYKA CHORÓB UKEADU SERCOWO- -NACZYNIOWEGO A ICH ZACHOWANIA ZDROWOTNE
}

\section{THE KNOWLEDGE OF PATIENTS IN THE DISTRICT CLINIC IN BIAŁA PODLASKA WITH REGARD TO THE RISK FACTORS FOR CARDIOVASCULAR DISEASES AND THEIR HEALTH BEHAVIOURS}

\author{
Małgorzata Siedlecka1 ${ }^{1(\mathrm{~A}, \mathrm{~B}, \mathrm{C}, \mathrm{D}, \mathrm{E}, \mathrm{F})}$, Wioletta Żukiewicz-Sobczak ${ }^{1(\mathrm{~A}, \mathrm{E}, \mathrm{F})}$ \\ ${ }^{1}$ Państwowa Szkoła Wyższa im. Papieża Jana Pawła II w Białej Podlaskiej
}

\begin{abstract}
Siedlecka, M., Żukiewicz-Sobczak, W. (2018). Wiedza pacjentów przychodni rejonowej POZ w Białej Podlaskiej na temat czynników ryzyka chorób układu sercowo-naczyniowego a ich zachowania zdrowotne. Rozprawy Społeczne, 12(3), 79-83. https://doi.org/10.29316/rs.2018.29

Wkład autorów:

A. Zaplanowanie badań

B. Zebranie danych

C. Dane - analiza i statystyki

D. Interpretacja danych

E. Przygotowanie artykułu

F. Wyszukiwanie i analiza literatury

G. Zebranie funduszy

Streszczenie

Wstęp. Celem niniejszej pracy była ocena stanu wiedzy pacjentów rejonowej przychodni POZ na temat czynników ryzyka chorób układu sercowo-naczyniowego, a także ogólna charakterystyka czynników ryzyka chorób układu krążenia oraz metody zapobiegania tym schorzeniom.

Materiał i metody. Badaniem objęto pacjentów rejonowej poradni na terenie powiatu bialskiego. Grupę badaną stanowiło 100 osób w tym 47 mężczyzn i 53 kobiety. Zastosowaną metodą badania była metoda sondażu diagnostycznego z wykorzystaniem kart ankiet autorskiego projektu. Uzyskane wyniki badań opracowano statystycznie przy użyciu programów statystycznych. Wyniki. Najważniejszym czynnikiem ryzyka wśród badanych respondentów był stres, brak aktywności fizycznej oraz niezdrowe i nieregularne odżywianie się, nadwaga, a także otyłość.

Wnioski. Na podstawie przeprowadzonych badań wysunięto następujące wnioski: 1 . W badanej populacji głównym czynnikiem ryzyka był stres. 2. Badani pacjenci wykazują dużą świadomość zasad zdrowego stylu życia oraz prawidłowego odżywiania.
\end{abstract}

Tabele: 0

Ryciny: 10

Literatura: 9

Otrzymano: lipiec 2017

Zaakceptowano: sierpień 2017
Słowa kluczowe: czynniki ryzyka, choroby układu sercowo-naczyniowego, świadomość pacjentów

\section{Summary}

Introduction. The aim of this study was to assess the state of knowledge among patients in the local health care clinic about cardiovascular disease risk factors, as well as the general characteristics of risk factors for cardiovascular diseases and methods of preventing these diseases.

Material and methods. The study included patients from the local counselling centre in the Biała Podlaska District. The study group consisted of 100 people, including 47 men and 53 women. The applied research method was the method of a diagnostic survey using questionnaire cards designed by the author. The obtained results were statistically analysed using statistical programs. Results. The most important risk factor reported by the respondents was stress, lack of physical activity as well as unhealthy and irregular nutrition, overweight as well as obesity.

Conclusions. The following conclusions were made on the basis of the conducted research: 1 . Stress was the main risk factor in the researched population. 2 . Researched patients are highly aware of the principles of healthy lifestyle and appropriate nutrition.

Keywords: risk factors, cardiovascular diseases, patients' awareness

\section{Wstęp}

Postęp techniczny, który dokonał się w drugiej połowie dwudziestego wieku w znacznym stopniu przyczynił się do niekorzystnego wpływu na styl życia ludzi. Zaistniały nieprawidłowe wzorce zachowań jak: palenie papierosów, picie alkoholu, złe nawyki żywieniowe, mała aktywność fizyczna, nieumiejętność odpoczynku i relaksu oraz olbrzy- mi stres. Takie nieodpowiednie postawy przyczyniły się do zaburzeń w stanie zdrowia i stały się skutkiem występowania wielu chorób m.in.: układu krążenia (Juszczyk, 2010). Od wielu lat najczęstszą przyczyną śmiertelności w Polsce są choroby układu krążenia, które w 2002 roku według Głównego Urzędu Statystycznego obejmowały 47\% wszystkich zgonów (Ślusarska, Zarzycka, 2004).

Adres korespondencyjny: Małgorzata Siedlecka, Państwowa Szkoła Wyższa im. Papieża Jana Pawła II w Białej Podlaskiej, Wydział Nauk o Zdrowiu i Nauk Społecznych, ul. Sidorska 95/97, 21-500 Biała Podlaska, e-mail: gosia19720610@o2.pl, tel.: 833449900 ORCID: Wioletta Żukiewicz-Sobczak: https://orcid.org/0000-0002-0142-5102 Copyright by: Państwowa Szkoła Wyższa im. Papieża Jana Pawła II w Białej Podlaskiej, Małgorzata Siedlecka, Wioletta Żukiewicz-Sobczak 
Choroby układu krążenia stanowią grupę schorzeń o olbrzymim znaczeniu społecznym i medycznym ze względu na występowanie, a także ich następstwa. Do najistotniejszych należą:

- choroba niedokrwienna serca (w Polsce występuje ok. 1500000 osób),

- nadciśnienie tętnicze (w naszym kraju stwierdza się u ok. 8500000 osób),

- wady serca,

- zwyrodnieniowe i zapalne choroby serca,

- niewydolność krążenia,

- miażdżyca tętnic

- zaburzenia rytmu serca (Woynarowska, 2008).

Rezultatem chorób układu krążenia są ogólne upośledzenia sprawności organizmu, jak również obniżenie jakości życia, co stanowi główną przyczynę późniejszej absencji chorobowej oraz inwalidztwo (Daniluk, Jurkowska, 2005). Zminimalizowanie powikłań tych chorób jest niemożliwe tylko przez rozwój metod ich leczenia, ale przede wszystkim dzięki wdrażanym programom prewencyjnym, zmniejszającym zapadalność na tego rodzaju schorzenia (Mandecki, 2005).

Zdrowie każdego z nas zależy od wielu czynników, możemy je przedstawić w czterech zasadniczych grupach: styl życia (50-60\%), środowisko fizyczne oraz życie społeczne i praca (ok. 20\%), czynniki genetyczne (ok. 20\%), opieka zdrowotna (10-15\%) (Kasprzak, Plewka, 2011).

Czynniki chorób sercowo-naczyniowych można podzielić na:

- czynniki ryzyka niepodlegające modyfikacji, do których zaliczamy: wiek, płeć męską, kobiety czas po menopauzie, obciążenia rodzinne,

- czynniki ryzyka podlegające modyfikacji: styl życia (Kaszuba, Nowicka, 2011).

Na przestrzeni lat stworzono dużo skutecznych programów profilaktyki chorób cywilizacyjnych. Możemy wyróżnić dwa podejścia do prewencji chorób układu sercowo-naczyniowego: strategia ogólno populacyjna - która skupia się na całej populacji osób chorych jak i zdrowych oraz strategia wysokiego ryzyka - która koncentruje się na ciągłym wyszukiwaniu ludzi zagrożonych chorobami krążenia i objęciem tej grupy pacjentów zwiększoną opieką medyczną (Braunwald, Goldman, 2005).

\section{Materiał i metody}

Celem niniejszej pracy była ocena stanu wiedzy pacjentów rejonowej przychodni POZ na temat czynników ryzyka chorób układu sercowo-naczyniowego. Badaniem objęto populację pacjentów podstawowej opieki zdrowotnej poradni w Białej Podlaskiej. Osoby biorące udział w badaniu były stałymi pacjentami poradni i wcześniej zostały poinformowane o badaniu, a także zgodziły się na udział w projekcie. Grupę badaną stanowiło 100 osób powiatu bialskiego: w tym 53 kobiety oraz 47 mężczyzn. 47\% respondentów było w wieku od 50 do 60 lat, 29\% w wieku od 40 do 50 lat zaś 24\% ankietowanych było w wieku 30-40 lat. Zastosowaną metodą była metoda sondażu diagnostycznego z wykorzystaniem karty ankiet autorskiego projektu. W celu przeprowadzenia badania wykorzystano ankietę opracowaną dla tego projektu.

\section{Wyniki}

Na podstawie przedstawionego wykresu zauważono, że najważniejszym czynnikiem ryzyka wśród respondentów jest stres - dotyczy 76 osób, brak aktywności fizycznej oraz niezdrowe i nieregularne odżywianie się - to problem dotykający niemal takiej samej liczby ankietowanych, czyli 48 i 47 osób, nadwaga i otyłość oraz dodatni wywiad rodzinny stwierdzono u - 45 i 41 pacjentów. Najmniejszymi czynnikami ryzyka u badanej grupy było palenie tytoniu - 25 osób oraz cukrzyca - 18 osób (Rycina1.).

Narażenie na czynniki podlegające modyfikacji, które zostały ujęte w badaniu to: poziom cholesterolu we krwi, stężenie glukozy we krwi, poziom ciśnienia tętniczego, palenie papierosów, sposoby spędzania czasu wolnego oraz czas przeznaczony w tygodniu na aktywność fizyczną, narażenie na stres i umiejętność radzenia sobie z nim, prowadzenie zdrowego trybu życia, a także znajomość zasad prawidłowego odżywiania. Wyniki przedstawiają się następująco: $53 \%$ respondentów nie ma podwyższonego poziomu cholesterolu, u 45 \% wartość jest podwyższona zaś $2 \%$ ankietowanych nigdy nie wykonywała takiego badania (Rycina 2.).

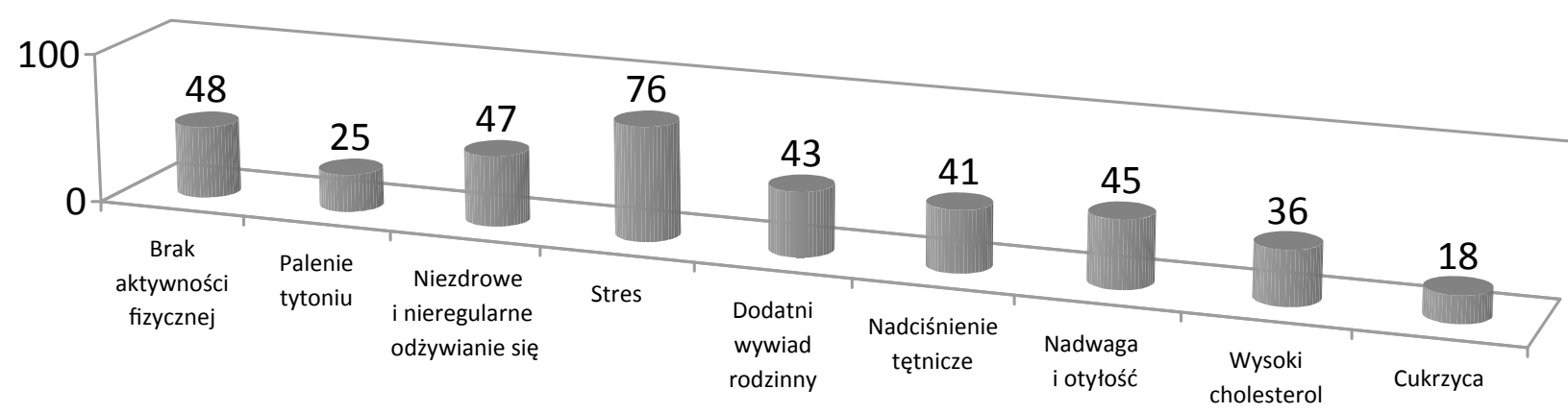

Rycina 1. Czynniki ryzyka, na które są narażeni ankietowani w ich opinii 


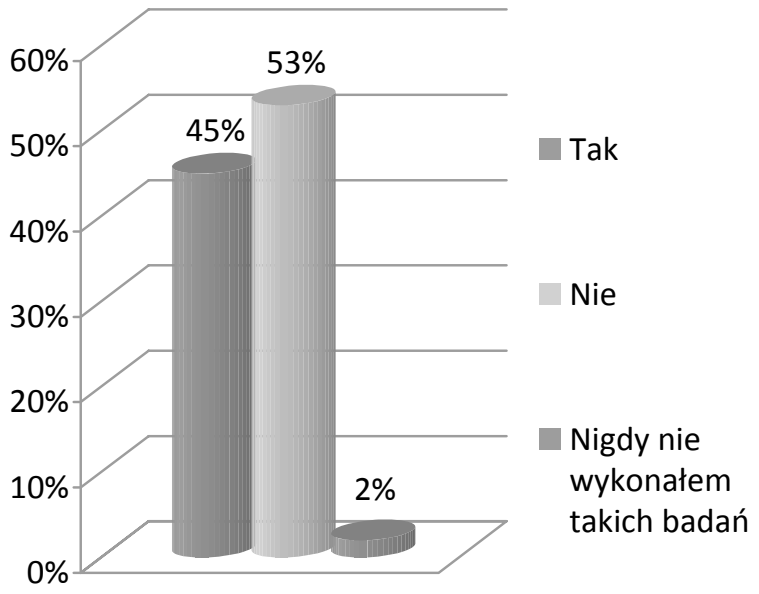

Rycina 2. Czy stwierdzono u Pana/ Pani podwyższony poziom cholesterolu we krwi?

Podwyższone stężenie glukozy we krwi zauważono u $24 \%$ respondentów, $72 \%$ osób nie ma takiego problemu, zaś $2 \%$ osób nigdy nie wykonywało kontroli stężenia cukru we krwi (Rycina 3).

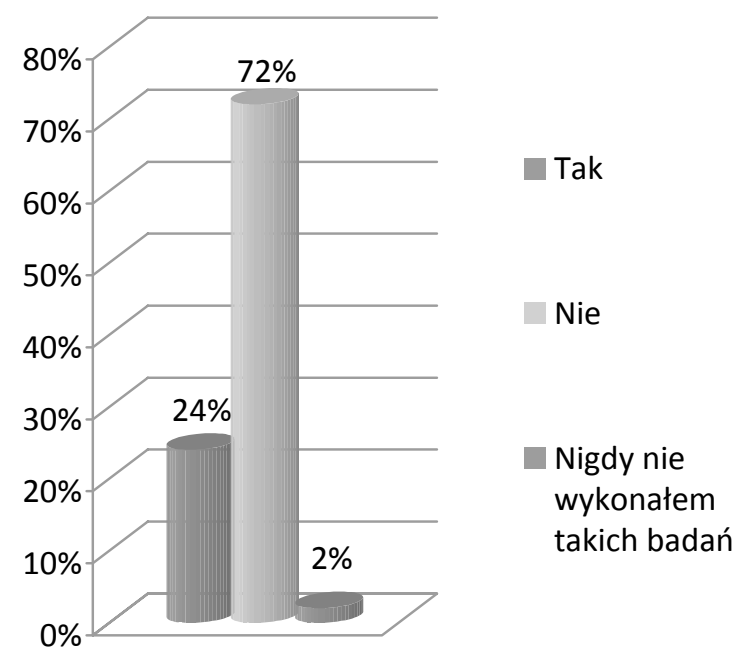

Rycina 3. Czy stwierdzono u Pana/Pani podwyższone stężenie glukozy we krwi?

53\% ankietowanych posiada wartość ciśnienia tętniczego w normie, 36\% respondentów ma podwyższony poziom ciśnienia, a u 11\% osób wartość ta jest obniżona (Rycina 4.).

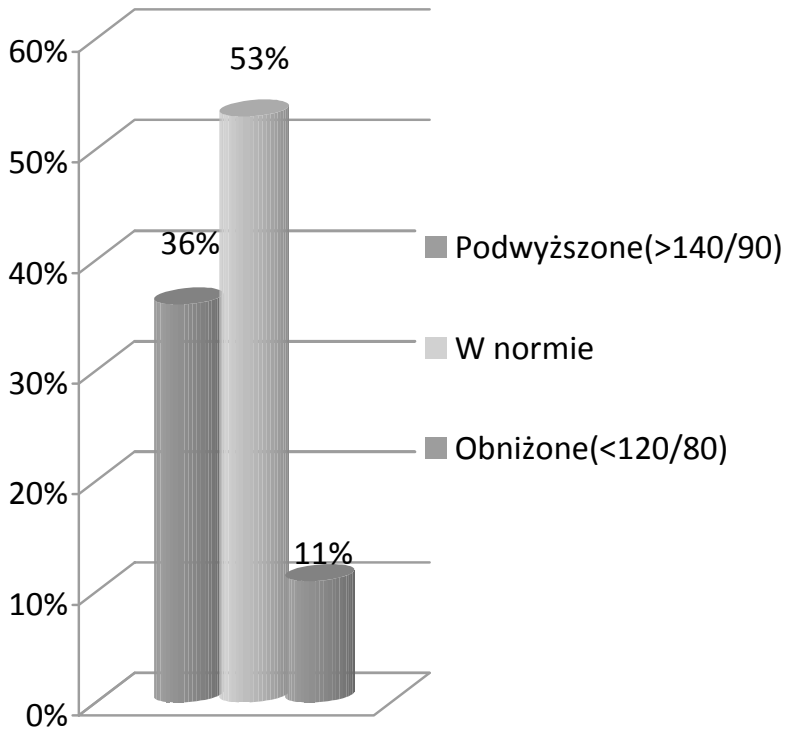

Rycina 4. Jaka jest wartość Pana/Pani ciśnienia tętniczego?

Badanie ukazuje, iż 86\% ankietowanych pacjentów posiada wiedzę na temat zdrowego stylu życia zaś $14 \%$ nie zna zasad prowadzenia zdrowego trybu życia (Rycina 5.).

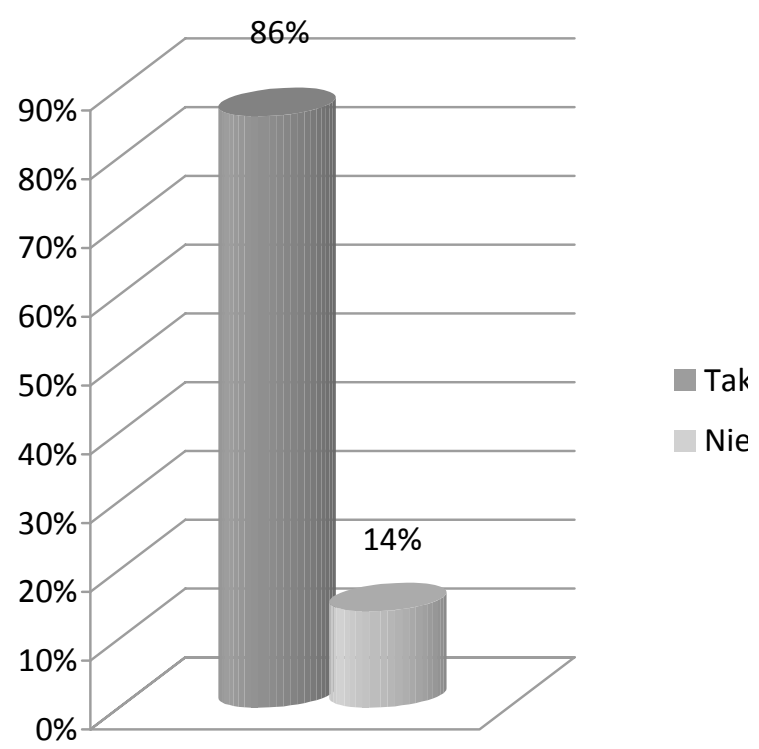

Rycina 5. Czy zna Pan/ Pani zasady zdrowego stylu życia?

92\% ankietowanych jest świadomych stosowania reguł prawidłowego żywienia, a jedynie $8 \%$ nie posiada informacji w tej dziedzinie (Rycina 6.). 


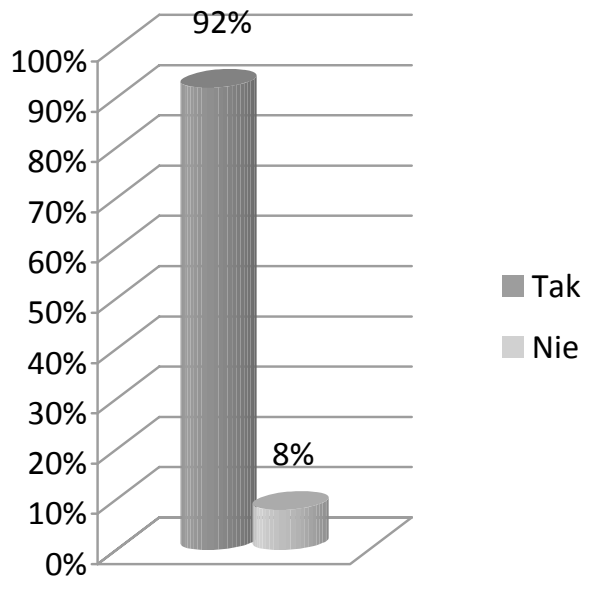

Rycina 6. Czy zna Pan/Pani zasady prawidłowego odżywiania się?

Stwierdzono, że 89\% pacjentów deklaruje narażenie na stres $\mathrm{w}$ swoim środowisku bytowania, a tylko $11 \%$ ankietowanych twierdzi, iż jest wolnych od tego czynnika (Rycina 7.).

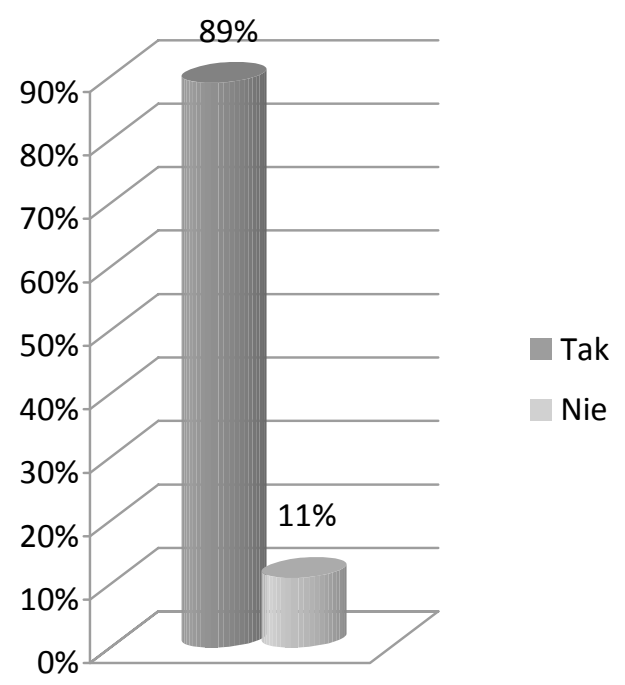

Rycina 7. Czy jest Pan/Pani narażona na stres?

Prezentowane dane ukazują skalę problemu, ponieważ 51\% pacjentów jest w stanie zapanować nad czynnikami stresującymi występującymi w ich środowiskach bytowania, a 49\% osób badanych nie potrafi radzić sobie ze stresem (Rycina 8.).

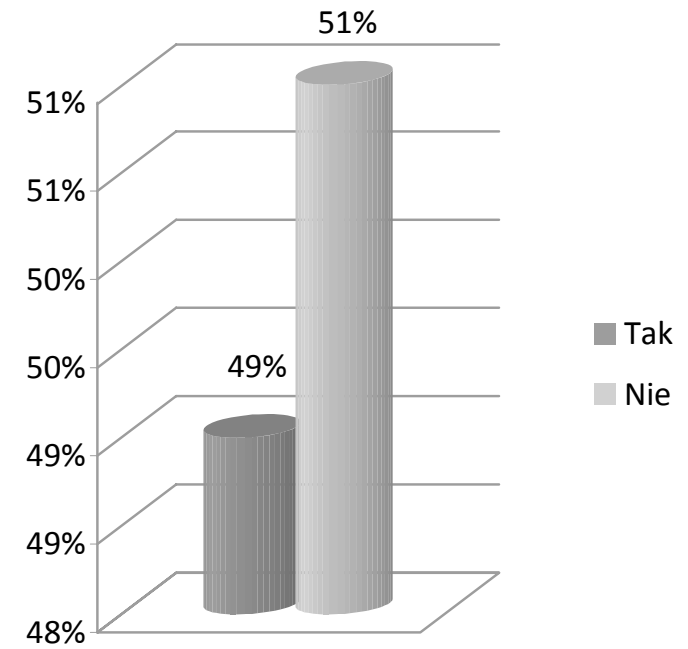

Rycina 8. Czy potrafi Pan/Pani radzić sobie ze stresem?

Z przedstawionych danych stwierdzono, że $44 \%$ respondentów poświęca jedynie $0,5 \mathrm{~h}$ w tygodniu na aktywność fizyczną, $24 \%$ badanych wykazuje jakąś aktywność od 0,5 do $1 \mathrm{~h}$ w tygodniu, zaś $22 \%$ respondentów ćwiczy od 1 do $1,5 \mathrm{~h}$ w ciągu tygodnia, a tylko $10 \%$ pacjentów jest aktywnych fizycznie powyżej 1,5 h w tygodniu (Rycina 9.).

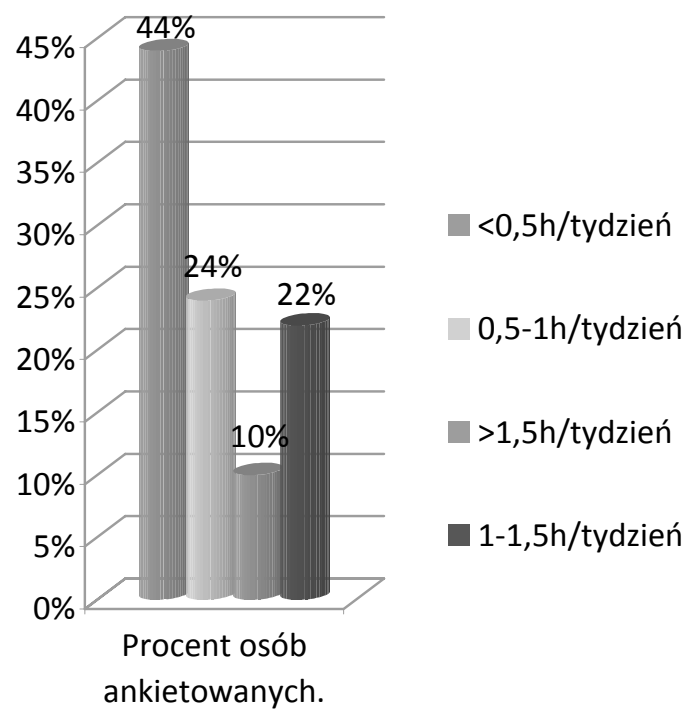

Rycina 9. Ile czasu w trakcie tygodnia poświęca Pan/Pani na aktywność fizyczną?

Narażenie na czynnik niepodlegający modyfikacji, jakim jest obciążenie rodzinne prezentuje się następująco: $77 \%$ osób ankietowanych deklaruje iż członkowie najbliższej rodziny są dotknięci chorobami układu sercowo-naczyniowego, a tylko 23\% respondentów zaprzecza występowania takich chorób u osób z najbliższej rodziny (Rycina 10.). 


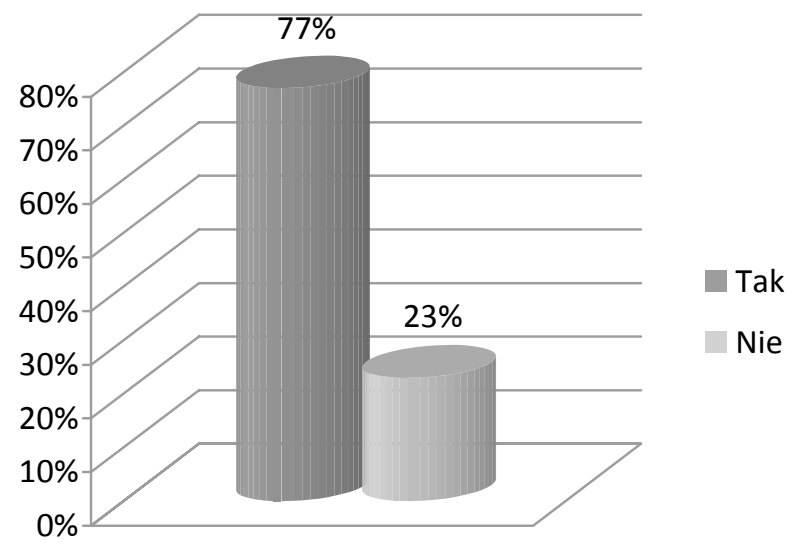

Rycina 10. Czy w Pana/ Pani najbliżej rodzinie występowały choroby układu sercowo- naczyniowego?

\section{Wnioski}

W badanej populacji głównym czynnikiem ryzyka okazał się stres oraz obciążenie rodzinne. Przeważająca liczba ankietowanych osób nie umie radzić sobie z permanentnym stresem. Poważnym problemem wśród badanych pacjentów jest niska aktywność fizyczna. Bardzo pozytywny wynikiem uzyskanych badań jest wysoka świadomość respondentów odnośnie znajomości zasad zdrowego stylu życia oraz racjonalnego odżywiania. Wyniki badania wskazują, że respondenci posiadają prawidłowe wartości glukozy i ciśnienia tętniczego.

\section{Literatura:}

1. Braunwald, E., Goldman, L. (2005). Kardiologia. Warszawa: Wydawnictwo „Elsevier Urban \& Partner”.

2. Daniluk, J., Jurkowska, G. (2005). Zarys chorób wewnętrznych dla studentów pielęgniarstwa. Warszawa: Wydawnictwo Lekarskie PZWL.

3. Juszczyk, M. (2010). Wybrane zagadnienia z edukacji zdrowotnej. Kielce: Wydawnictwo „WSEPiNM”.

4. Kasprzak, J., Plewka, M. (2011). Kardiologia - co nowego? Wrocław: Wydawnictwo „Cornetis” Sp. z o.o.

5. Kaszuba, D., Nowicka, A. (2011). Pielęgniarstwo kardiologiczne podręcznik dla studiów medycznych.Warszawa: Wydawnictwo Lekarskie PZWL.

6. Kokot, F. (2001). Choroby wewnętrzne. Warszawa: Wydawnictwo Naukowe PWN.

7. Mandecki, T. (2005). Kardiologia. Warszawa: Wydawnictwo Lekarskie PZWL.

8. Ślusarska, B., Zarzycka, D. (2004). Podstawy pielęgniarstwa tom I. Założenia teoretyczne. Warszawa: Wydawnictwo Lekarskie PZWL.

9. Woynarowska, B. (2008). Edukacja zdrowotna. Podręcznik akademicki. Warszawa: Wydawnictwo Naukowe PWN. 